Article

\title{
Simultaneous Study of the Growth and Grazing Mortality Rates of Microbial Food Web Components in a Mediterranean Coastal Lagoon
}

\author{
David Pecqueur $^{1, * \mathbb{D}}$, Justine Courboulès ${ }^{2}$, Cécile Roques ${ }^{2}$, Sébastien Mas ${ }^{3}$, Romain Pete ${ }^{4}$, Francesca Vidussi ${ }^{2}$ (D) \\ and Behzad Mostajir ${ }^{2}$
}

check for

updates

Citation: Pecqueur, D.; Courboulès,

J.; Roques, C.; Mas, S.; Pete, R.;

Vidussi, F.; Mostajir, B. Simultaneous Study of the Growth and Grazing Mortality Rates of Microbial Food Web Components in a Mediterranean Coastal Lagoon. Diversity 2022, 14, 186. https://doi.org/10.3390/ d14030186

Academic Editors: Michael Wink and An Yi Tsai

Received: 26 January 2022

Accepted: 2 March 2022

Published: 4 March 2022

Publisher's Note: MDPI stays neutral with regard to jurisdictional claims in published maps and institutional affiliations.

Copyright: (C) 2022 by the authors. Licensee MDPI, Basel, Switzerland. This article is an open access article distributed under the terms and conditions of the Creative Commons Attribution (CC BY) license (https:// creativecommons.org/licenses/by/ $4.0 /)$
1 Sorbonne Université, CNRS (Centre National de la Recherche Scientifique), Observatoire Océanologique de Banyuls-sur-Mer, FR 3724, 66650 Banyuls-sur-Mer, France

2 MARBEC (Marine Biodiversity, Exploitation and Conservation), University Montpellier, CNRS, Ifremer, IRD, 34095 Montpellier, France; justine.courboules@cnrs.fr (J.C.); cecile.roques@cnrs.fr (C.R.); francesca.vidussi@cnrs.fr (F.V.); behzad.mostajir@umontpellier.fr (B.M.)

3 MEDIMEER (Mediterranean Platform for Marine Ecosystems Experimental Research), OSU OREME, University Montpellier, CNRS, IRD, INRAE, 34200 Sète, France; sebastien.mas1@umontpellier.fr

4 SMBT, Syndicat mixte du bassin de Thau, 34400 Sète, France; r.pete@smbt.fr

* Correspondence: david.pecqueur@obs-banyuls.fr

\begin{abstract}
The abundances of 17 cytometric groups encompassing four groups of bacteria, three groups of cyanobacteria, six groups of eukaryotic picophytoplankton $(<2-3 \mu \mathrm{m})$, and four groups of small eukaryotic nanophytoplankton (between 3 and $6 \mu \mathrm{m}$ ) were studied in the Thau Lagoon across different seasonal conditions. Among them, the growth $(\mu)$ and mortality rates due to grazing (g) of 12 groups of bacteria, cyanobacteria, and eukaryotic pico- and nanophytoplankton were simultaneously studied in the Thau Lagoon via four dilution experiments across different seasonal conditions. The abundances of heterotrophic flagellates and ciliates and their potential predators were studied and linked to prey mortality. Bacteria were more active than phytoplankton and displayed the highest growth and grazing mortality rates. Most studied groups had g: $\mu$ ratios $>1$, suggesting that predators efficiently grazed and transferred these preys. Surprisingly, the observed variations in predator abundance across seasons did not necessarily correspond with changes in grazing pressure. The significant positive relationship found between water temperature and bacterial grazing mortality rates and the reverse trend observed for larger eukaryotic prey suggested that warmer water increases small prokaryote transfer to higher trophic levels but disadvantages larger eukaryotic prey transfer.
\end{abstract}

Keywords: bacteria; dilution; food web; growth; grazing; Mediterranean coastal lagoon; phytoplankton

\section{Introduction}

Bacteria (including archaea, hereafter referred to simply as bacteria) and phytoplankton are major components of the plankton food web and play a fundamental role in the functioning of marine ecosystems and in biogeochemical cycles [1,2]. Growth and grazing on bacteria and picophytoplankton are the major processes that define the structure of the microbial food web (MFW) in terms of biomass accumulation and the transfer of biomass to higher trophic levels. It is well known that bacterial and phytoplankton growth is mostly controlled by the availability of resources such as light and nutrients [3], while their metabolism is influenced by temperature [4,5]. Moreover, microzooplankton grazing is responsible for a major part of the transfer of bacterial and small phytoplanktonic biomass to upper trophic levels [6,7]. The failure to take into account microzooplankton grazing could be a source of error when estimating carbon cycling [7].

Several methods have been used to assess the microzooplankton grazing rate of bacteria or phytoplankton, such as (1) the use of fluorescent tracers [8]; (2) dilution reducing the rates of encounters between prey and predators [9]; (3) measurements of the activities 
of the digestive enzymes of grazers [10]; (4) selective filtration [11]; and (5) the addition of eukaryotic inhibitors [12]. Among these methods, the dilution technique is used to estimate not only nano- and microzooplankton grazing mortality rates of prey but also, simultaneously, their growth rates [9]. This technique consists of the dilution a whole sea water sample with different amounts of filtered sea water from the same source. This creates a gradient of predator abundances and, thus, grazing pressures along the various degrees of dilution. This technique has several advantages: First, it is not intrusive, involving few manipulations, and second, it provides simultaneously the growth rates of prey and the related grazing mortality rates. This method is based on three main assumptions: (1) The prey growth rate is not affected by dilution, (2) the grazing mortality is linearly proportional to the prey concentration, and (3) the prey growth rate is exponential. However, the first two assumptions may be problematic [13]. Notably, the first assumption implies the addition of nutrients to avoid the nutrient limitation of the communities studied during the incubation time in closed bags. However, if the aim of the study is to assess the growth and mortality rates of organisms in a potentially nutrient-limited environment, nutrient addition would alter these rates, and all measured rates would be higher than the natural rates. The second assumption implies that grazing mortality rates vary in direct proportion to dilution. In fact, the differences in the relative densities of grazers established in initial dilutions are unlikely to be maintained throughout the experiment, and the clearance rate of grazers is not constant [13]. Although this technique has some limitations, it is still the only method providing simultaneous estimations of growth and grazing mortality rates. It has been used for approximately 40 years and is still being used for a wide variety of ecosystems $[7,14-16]$.

However, few studies estimating the growth $(\mu)$ and grazing $(\mathrm{g})$ mortality rates of the different components of microbial communities have been carried out in the Mediterranean Sea [17-20], and a lack of knowledge still exists for a large number of specific ecosystems, such as coastal lagoons. The objectives of the present study were to characterize the growth $(\mu)$ and grazing $(g)$ mortality rates of the microbial food web components of a coastal lagoon in various seasonal conditions and to assess their g: $\mu$ ratios, reflecting their transfer:production efficiencies. Therefore, this study presents the results of four series of dilution experiments carried out in the atmospheric seasons of autumn 2008 (October) and spring and summer 2009 (May, June, and July) in the surface waters of a productive Mediterranean lagoon (Thau, South of France). This is the first investigation detecting and studying 17 cytometric groups, encompassing four groups of bacteria, three groups of cyanobacteria, six groups of eukaryotic picophytoplankton $(<2-3 \mu \mathrm{m})$, and four groups of small eukaryotic nanophytoplankton (between 3 and $6 \mu \mathrm{m}$ ). Among these groups, the significant $\mu$ and $g$ values of 12 cytometric microbial groups were simultaneously estimated. In addition, the potential predators of these groups, such as heterotrophic flagellates and ciliates, were identified and enumerated to evaluate their relationships with the estimated $\mu$ and $g$ values of the microbial groups.

\section{Material and Methods}

\subsection{Dilution Experiments and Seawater Sampling}

Four dilution experiments were carried out in the Thau Lagoon on 7 October 2008 (autumn), 20 May 2009 (spring), 18 June 2009 (spring), and 21 July 2009 (summer). Please note that no dilution experiment was carried out in the winter season. The Thau Lagoon covers $75 \mathrm{~km}^{2}$ and is located on the French coast in the northwestern Mediterranean region $\left(43^{\circ} 24^{\prime} \mathrm{N}, 3^{\circ} 36^{\prime} \mathrm{E}\right.$, Figure 1). Seawater was collected from the surface of the lagoon $(0.1 \mathrm{~m})$ by immersing pre-washed $(10 \% \mathrm{HCl})$ polyethylene carboys. Samples were taken from a shallow creek called "Crique de l'Angle", to the northeast of the lagoon, in October 2008, and near the MEDIMEER (Mediterranean platform for Marine Ecosystem Experimental Research, $43^{\circ} 24^{\prime} 53^{\prime \prime}$ N, $3^{\circ} 41^{\prime} 16^{\prime \prime}$ E) pontoon, located near the "Crique de l'Angle" site and in the eastern part of the lagoon, for the other three experiments (May, June and July). The seawater was immediately carried to nearby laboratories and gravimetrically filtered through $200-\mu \mathrm{m}$ nylon mesh. A portion of each water sample was then gravimetrically 
filtered through an in-line $0.2-0.8-\mu \mathrm{m}$ cartridge that had been rinsed with $1 \mathrm{~L}$ of Milli-Q water and $1 \mathrm{~L}$ of seawater. Different fractions of $200-\mu \mathrm{m}$ filtered sea water were mixed with $0.2-0.8-\mu \mathrm{m}$-filtered sea water to obtain five dilution series $(0.10,0.25,0.50,0.75$, and 1.00 whole water), except for the samples collected in the 7 October 2008 experiment, for which the 0.10 dilution was omitted. Each 1-L dilution was carried out in triplicate using sterile, transparent polyethylene bags (Whirl-Pak ${ }^{\circledR}$ Sample Bag, Sigma-Aldrich, St. Louis, MO, USA). Care was taken to prevent air from being trapped when closing the bags. The Whirl-Pak bags were incubated immediately in the surface water of the lagoon near the MEDIMEER pontoon for $24 \mathrm{~h}$ under natural light, agitation, and temperature conditions [9]. Samples were taken only from the $200-\mu \mathrm{m}$ filtered 1.00 water triplicates at the beginning of the experiment $\left(T_{0}\right)$ to measure the nutrients and abundances of the microorganisms, as described below. The microorganism abundances in the diluted fractions at $T_{0}$ were calculated in proportion to those determined in the 1.00 triplicates. After the 24-h incubations $\left(T_{24}\right)$, the samples were taken from all Whirl-Pak bags to measure their microorganism abundances, with the exception of ciliates, for which samples were taken only from the 0.50 and 1.00 triplicates, and nutrients, for which samples were taken only from the 1.00 whole water triplicates.

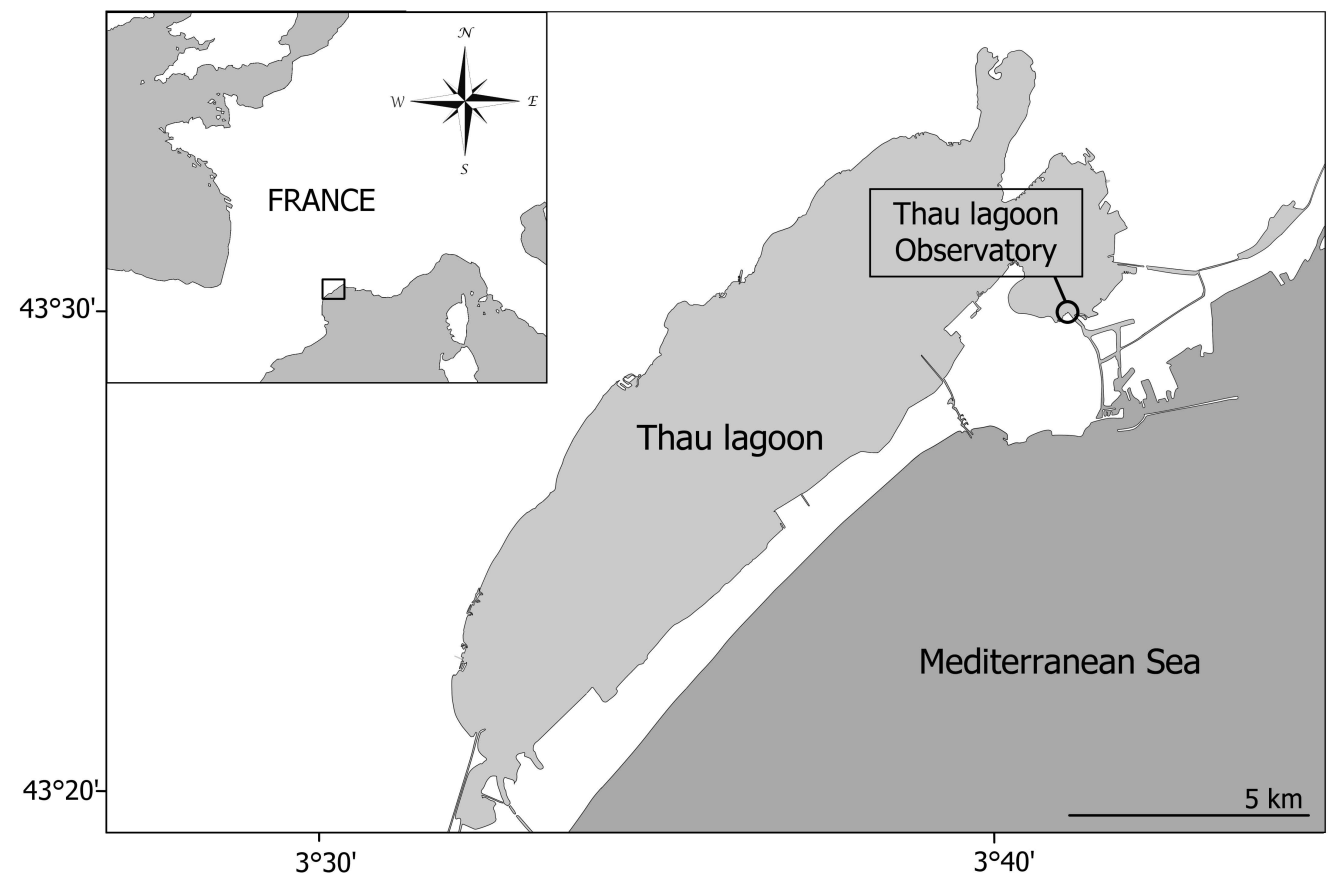

Figure 1. Area of sampling and experiment in Thau Lagoon Observatory (France) in the northwestern Mediterranean Sea.

\subsection{Chemical Sampling and Analysis}

The nutrient concentrations were analyzed using samples $(100 \mathrm{~mL})$ filtered through pre-combusted $\left(450{ }^{\circ} \mathrm{C}\right.$ for $6 \mathrm{~h} \mathrm{Whatman}{ }^{\circledR}$, Maidstone, UK) GF/F 0.7- $\mu \mathrm{m}$ glass fiber filters and then frozen $\left(-20^{\circ} \mathrm{C}\right)$ in acid-cleaned polyethylene bottles until analysis. The concentrations of nitrates $\left(\mathrm{NO}_{3}+\mathrm{NO}_{2}\right)$, soluble reactive phosphorus (SRP), and silicates $\left(\mathrm{SiO}_{4}\right)$ were then analyzed using an automatic analyzer (Skalar, Breda, The Netherlands) with standard nutrient analysis methods [21]. Temperature and salinity were measured using a multi-parameter sensor (EC300, VWR International, Radnor, PA, USA).

\subsection{Bacteria, Cyanobacteria, and Eukaryotic Picophytoplankton and Nanophytoplankton Sampling and Analyses}

Two 1.6-mL sample aliquots were fixed with $2 \%$ pre-filtered formaldehyde (using a $0.02-\mu \mathrm{m}$ Swinnex filter) for the analyses of bacteria, cyanobacteria, and small phytoplankton. 
The samples were frozen in liquid nitrogen $\left(-196^{\circ} \mathrm{C}\right)$ and then stored at $-80{ }^{\circ} \mathrm{C}$ until analysis. Three separate analyses were performed to count (1) bacteria, (2) cyanobacteria and eukaryotic picophytoplankton $(<2-3 \mu \mathrm{m})$, and (3) nanophytoplankton (3-10 $\mu \mathrm{m})$ using a FACSCalibur flow cytometer (Becton Dickinson, Franklin Lakes, NJ, USA) equipped with an air-cooled laser providing $15 \mathrm{~mW}$ at $488 \mathrm{~nm}$ with a standard filter setup. Becton Dickinson Trucount ${ }^{\mathrm{TM}}$ beads (Figure 2) were used to calculate the abundances of the various cells, as described by Pecqueur et al. [22]. For the bacteria counts, the samples were stained with SYBR Green I (S7563, Invitrogen; $\%$ final concentration) and incubated at room temperature in the dark for $20 \mathrm{~min}$.
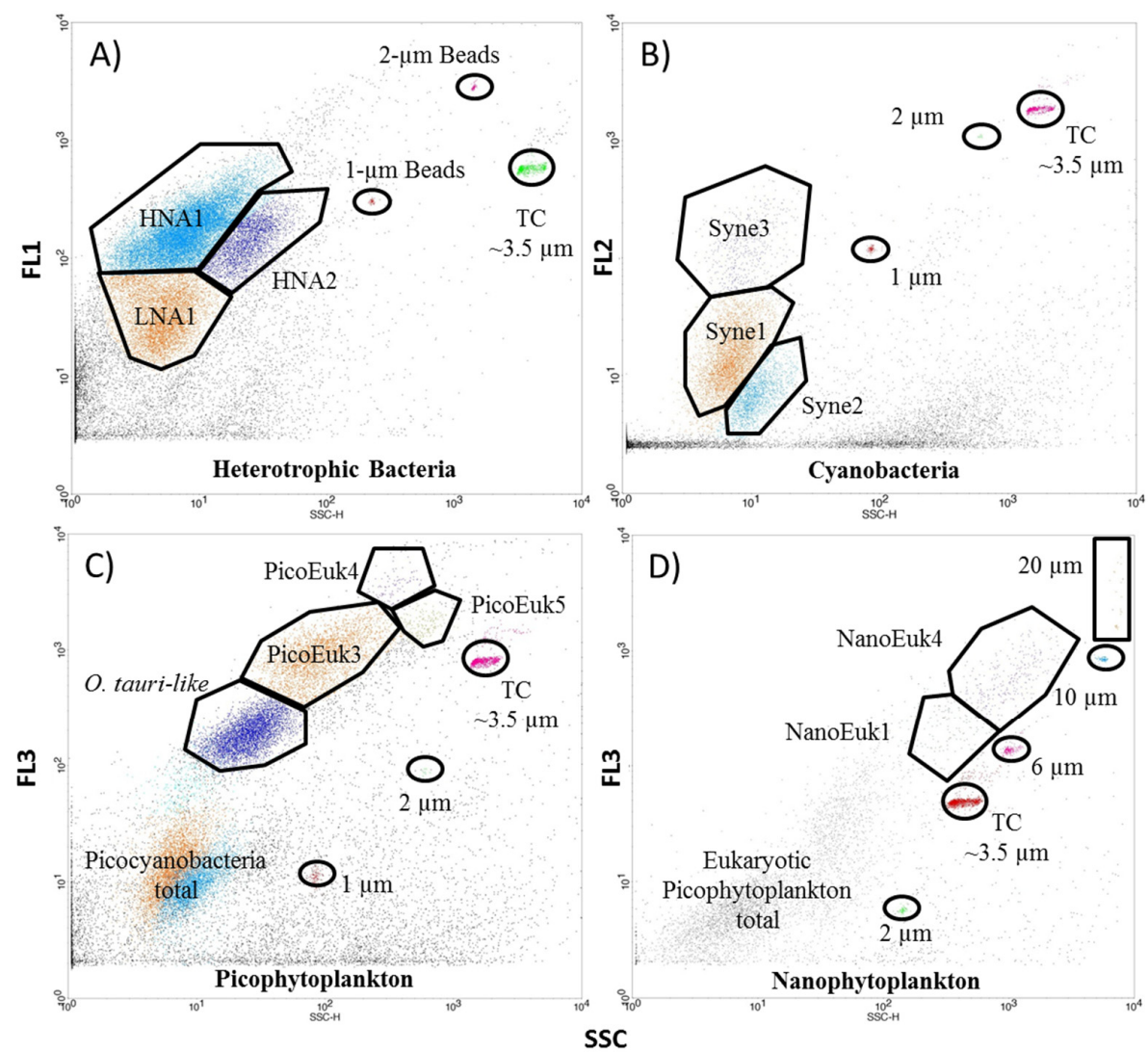

Figure 2. (Color). Examples of cytograms showing the main studied groups of bacteria (A), cyanobacteria (B), eukaryotic pico- (C), and nanophytoplankton (D). TC indicates TruCount ${ }^{\mathrm{TM}}$, and beads are mentioned by their size in $\mu \mathrm{m}$. For each of the cytograms, fluorescence is shown on the y-axis and SSC on the x-axis: green for bacteria, orange for cyanobacteria, and red for eukaryotic pico- and nanophytoplankton. Note that some studied groups are not shown in this figure (LNA2, PicoEuk1 and 2, NanoEuk2 and 3).

For the analyses of cyanobacteria and eukaryotic pico-and nanophytoplankton, autofluorescence of photosynthetic pigments was used. Every microbial population was studied, as described in Marie et al. [23,24], Gasol et al. [25], Jochem [26], and Morán et al. [27]. Cells were excited at $488 \mathrm{~nm}$ and detected and enumerated according to their specific side scattering (SSC) properties and fluorescence (natural or induced). Artificially induced green fluorescence (FL1 530/30 nm) was used for the bacterial analysis. The natural orange fluorescence of phycoerythrin (FL2 585/42 nm BP) was used to detect cyanobacteria. Eukaryotic pico- and nanophytoplankton ( $<2-3$ and 3-20 $\mu \mathrm{m}$, respectively) were detected and analyzed using natural red chlorophyll fluorescence (chl FL3 $670 \mathrm{~nm}$ $\mathrm{LP})$. The flow rate of the cytometer was set to low $\left(15 \mu \mathrm{L} \mathrm{m}{ }^{-1}\right)$ for the bacteria analysis

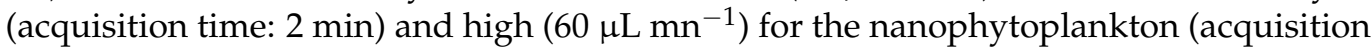
time: $5 \mathrm{~min}$ ), eukaryotic picophytoplankton (acquisition time: $3 \mathrm{~min}$ ), and cyanobacteria 
(acquisition time: $3 \mathrm{~min}$ ) analyses. The flow cytometer data were analyzed using CellQuest Pro (Becton Dickinson, Franklin Lakes, NJ, USA).

\subsection{Heterotrophic Flagellate and Ciliate Sampling and Analyses}

For the analysis of heterotrophic flagellates (HFlag), 40-mL samples were preserved in a $6 \%$ formaldehyde solution and stored in a cold $\left(4^{\circ} \mathrm{C}\right)$ room in the dark until analysis. Subsamples of $10 \mathrm{~mL}$ were stained using $4^{\prime}, 6$-diamidino-2-phenylindole (DAPI) at a final concentration of $2.5 \mu \mathrm{g} \mathrm{mL}{ }^{-1}$. The HFlag counts and size measurements were performed using an epifluorescence microscope (Olympus AX70, London, UK) with UV illumination [28]. HFlags were assigned to four size classes according to their cell size diameter: $<3 \mu \mathrm{m}, 3-5 \mu \mathrm{m}, 5-10 \mu \mathrm{m}$, and 10-15 $\mu \mathrm{m}$.

For the aloricate ciliates (naked ciliates) and tintinnid counts and analyses, $125 \mathrm{~mL}$ of each water sample was preserved using $6 \%$ Lugol's iodine solution and kept in a cold $\left(4{ }^{\circ} \mathrm{C}\right)$ room in the dark until analysis. After allowing each sample $(100 \mathrm{~mL})$ to settle in an Utermöhl chamber for $24 \mathrm{~h}$, the aloricate ciliates and tintinnids were identified and enumerated using an inverted microscope (Olympus IX70). Several taxonomic guides and references were used for the identification [29-37].

\subsection{Data Processing and Statistical Analysis}

The apparent growth rates $\left(\mu_{a p p}\right.$, day $\left.^{-1}\right)$ of the prey were determined from the initial $\left(N i\right.$, cell $\left.\cdot \mathrm{mL}^{-1}\right)$ and final $\left(N f\right.$, cell $\left.\cdot \mathrm{mL}^{-1}\right)$ abundance estimates assuming an exponential model, as described in Equation (1) [9]:

$$
\mu_{a p p}=\ln (N f / N i) \times(1 / t)
$$

where $t$ (days) is the duration of the incubation time (in this study, $24 \mathrm{~h}$ ). The maximum growth rate (hereafter simply called growth and noted $\mu$ ) was estimated from the intercept of the linear regression analysis of the relationship between $\mu_{\text {app }}$ and the dilution factor ( $x$ : proportion of whole sea water in filtered water), when the probability of an encounter between prey and predators was hypothetically zero. Please note that viruses were not filtered during the dilution experiments; therefore, mortality induced by viruses was not encompassed in this study. The grazing mortality rate $\left(g\right.$, day $\left.^{-1}\right)$ was estimated from the slope of the linear regression [9]:

$$
\mu_{a p p}=\mathrm{g} x+\mu
$$

Model I regression theory [38] was applied to calculate the growth and grazing mortality rates from the apparent growth rates and dilution factors. Only significant linear regressions $(p<0.05)$ are presented and discussed hereafter. On rare occasions (less than $5 \%$ ), the significant linear regressions resulted in negative growth rates or positive grazing mortality rates; thus, these results were set to 0.01 and $0.00 \mathrm{day}^{-1}$, respectively, following the correction method of Landry and Calbet [39]. Moreover, when the boundary of populations was not very clear through dilution series and, therefore, very low abundances were found, the growth and grazing mortality rates were not calculated and only abundances of populations were presented and discussed.

To assess the impact of diversity on the grazing pressure, the diversity of aloricate ciliates was estimated using Shannon diversity's index ( $H$, no unit), as described in Equation (2):

$$
H=-\sum_{i=1}^{S} p i \ln p i
$$

where $S$ is the total number of species or groups in the aloricate ciliate community and $p_{i}$ is the proportion of $S$ made up of the $i$ th species.

The relationships between growth and grazing mortality rates, abundances, temperature, and nutrient concentrations were determined using Spearman correlation (Rho). Similarly, correlations between grazing mortality rates of phytoplankton, bacteria, or their 
respective abundances and flagellates' and ciliates' abundances, as well as correlations between groups' abundances, were tested. Correlations with a $p$-value $<0.05$ were considered significant. The data analysis was performed using R software (R-project), version R3.6.1.

\subsection{Calculation of $g: \mu$ Ratio}

This ratio was calculated by dividing $g$ by $\mu$ (no unit). If $g: \mu=1$, this result underlines that the cell production (growth rate) and transfer (grazing mortality rate) to a higher trophic level by grazing are in balance. If the ratio of $g: \mu$ is greater than 1 , the transfer to higher trophic levels is greater than the cell production. In contrast, if this ratio is less than 1, fewer cells are transferred to higher trophic levels and, therefore, cells accumulate at the bottom of the MFW [7].

\section{Results}

\subsection{Physical and Chemical Conditions for the Dilution Experiments}

The surface temperatures of the lagoon water ranged between 16.3 and $25.3^{\circ} \mathrm{C}$ during our experiments (Table 1). The surface water salinity was stable in all the seasons studied. The initial concentrations of nitrates were the lowest in May $\left(0.22 \mu \mathrm{mol} \mathrm{L}^{-1}\right)$ and highest in July $\left(0.60 \mu \mathrm{mol} \mathrm{L}{ }^{-1}\right)$, and the same trend was observed for the silicate concentrations (1.24 $\mu \mathrm{mol} \mathrm{L}{ }^{-1}$ and $17.83 \mu \mathrm{mol} \mathrm{L}{ }^{-1}$, respectively). The October and June concentrations were within these ranges. In contrast, the phosphorous concentrations were the highest in May $\left(0.12 \mu \mathrm{mol} \mathrm{L}^{-1}\right)$ and the lowest in July $(0.02 \mu \mathrm{mol} \mathrm{L}-1)$, leading to contrasted N:P ratio conditions being between 1.83 and 3.71 in October, May, and June, while reaching 30 in July (Table 1).

Table 1. Initial temperatures, salinity and nitrate levels, and phosphorus and silicate concentrations ( \pm SD) for each of the four dilution experiments carried out in October 2008, May 2009, June 2009, and July 2009. N.A indicates that the data are not available.

\begin{tabular}{|c|c|c|c|c|}
\hline $\begin{array}{c}\text { Physical and } \\
\text { Chemical Parameters }\end{array}$ & $\begin{array}{l}\text { October } \\
2008\end{array}$ & $\begin{array}{l}\text { May } \\
2009\end{array}$ & $\begin{array}{l}\text { June } \\
2009\end{array}$ & $\begin{array}{l}\text { July } \\
2009\end{array}$ \\
\hline Temperature $\left({ }^{\circ} \mathrm{C}\right)$ & 16.3 & 20.4 & 25.0 & 23.3 \\
\hline Salinity & 36.6 & N.A & 35.6 & 37.1 \\
\hline Nitrates $\left(\mu \mathrm{mol} \mathrm{L}{ }^{-1}\right)$ & $0.24 \pm 0.05$ & $0.22 \pm 0.04$ & $0.26 \pm 0.04$ & $0.60 \pm 0.01$ \\
\hline Phosphorus $(\mu \mathrm{mol} \mathrm{L}-1)$ & $0.09 \pm 0.02$ & $0.12 \pm 0.04$ & $0.07 \pm 0.01$ & $0.02 \pm 0.00$ \\
\hline Silicate $(\mu \mathrm{mol} \mathrm{L}-1)$ & $10.26 \pm 0.21$ & $1.24 \pm 0.25$ & $7.51 \pm 0.13$ & $17.83 \pm 0.07$ \\
\hline $\mathrm{N}: \mathrm{P}$ ratio & 2.66 & 1.83 & 3.71 & 30.00 \\
\hline
\end{tabular}

\subsection{Abundances of the MFW Components}

Four distinct groups of bacteria were observed [23,40-43]. These groups included two low-fluorescence (LNA1 and LNA2) and two high-fluorescence (HNA1 and HNA2) nucleic acid groups (see examples of cytograms in Figure 2). The total bacterial abundance ranged from 2.75 to $5.30 \times 10^{6}$ cells $\mathrm{mL}^{-1}$, with the lowest abundance observed in October and the highest abundance observed in July (Figure 3A). HNA1 was the most abundant bacterial group and was observed in every experiment, as was the LNA1 group. The HNA2 and LNA2 groups were observed only sporadically (Figure 3A). Three cyanobacteria groups (Figure 2B) sharing similar side scatter (SSC) and phycoerythrin fluorescence (FL2) intensities with the Synechococcus sp. genus were distinguished and called Syne1 and Syne3. The Syne1 and Syne3 groups were observed in all four experiments, whereas the Syne2 group was sporadic. Syne1, which also reached its maximal abundance in July, was the dominant cyanobacteria group, except in May (Figure 3B). However, compared to the other picophytoplankton groups (i.e., eukaryotic groups), the cyanobacteria abundances were relatively low throughout the study. Six groups of eukaryotic picophytoplankton (see examples of the main groups in Figure 2C) were observed. Two eukaryotic picophytoplankton groups with SSCs $<1 \mu \mathrm{m}$ were depicted: one with low fluorescence, 
identified as Ostreococcus tauri-like (referred to as O. tauri-like in the figure), and another with high fluorescence (referred to as PicoEuk1). Four other eukaryotic picophytoplankton groups were highlighted and characterized by their relative diameter size determined by their SSC intensities: PicoEuk2 $(0.5-1.5 \mu \mathrm{m})$, PicoEuk3 $(1-2 \mu \mathrm{m})$, PicoEuk4 $(1.5-2 \mu \mathrm{m})$, and PicoEuk5 (2-3 $\mu \mathrm{m})$. Eukaryotic picophytoplankton were, numerically, the dominant group in the picophytoplankton community in the four experiments, with an average of $4.04 \times 10^{4}$ cells $\mathrm{mL}^{-1}$ (Figure 3C). Since the mid-1990s, it has been known that a major part of the pico-eukaryotic community of the Thau Lagoon is composed of O. tauri [44-46]. Indeed, the most abundant phytoplankton group encountered during these experiments was O. tauri-like. The abundance of this group increased threefold from May to July (Figure 3C), while most of the five other picophytoplankton groups $(1-3 \mu \mathrm{m}$, mentioned as PicoEuk1 to PicoEuk5) were observed sporadically. Four groups of nanophytoplankton were distinguished (Figure 2D) and called NanoEuk1 $(2-4 \mu \mathrm{m})$, NanoEuk2 $(2-6 \mu \mathrm{m})$, NanoEuk3 $(4-6 \mu \mathrm{m})$, and NanoEuk4 $(4-8 \mu \mathrm{m})$. The NanoEuk1, NanoEuk3, and NanoEuk4 groups had low abundances (below $10^{3}$ cells $\mathrm{mL}^{-1}$ ), while the NanoEuk2 group had the highest abundance during October (Figure 3D). The abundance of the total HFlag community ranged between 79 and 1754 cells $\mathrm{mL}^{-1}$ (Figure 3E). Four size classes of HFlag, hereafter referred as Hflag1 $(<3 \mu \mathrm{m})$, HFlag2 $(\sim 4 \mu \mathrm{m})$, HFlag3 $(\sim 7 \mu \mathrm{m})$, and HFlag4 $(\sim 12 \mu \mathrm{m})$, were found in July, while only HFlag1 and HFlag 2 were observed in October, May, and June. The abundances and species' diversities of the aloricate ciliates and tintinnids studied during the four experiments highlighted that the aloricate ciliate abundances were higher in October and May than in June and July. In addition, four species of aloricate ciliates that ranged between 10 and $90 \mu \mathrm{m}$ were found to be generally dominant during these experiments. M. rubrum dominated the community in October, showing the highest abundance, reaching 1955 cells $\mathrm{L}^{-1}$, while Uronema sp. dominated in May, reaching 1268 cells L $^{-1}$ (Figure 3F). Strombidinopsis sp. and Strombidium sp. were observed mostly during June and July. The tintinnid community was mainly represented by Tintinnopsis sp., Eutintinnus sp., and Helicostomella sp., with sizes ranging between 60 and $200 \mu \mathrm{m}$, and the total tintinnid community reached its maximum abundance in October (Figure 3F). Correlations tests performed revealed a significant negative correlation between nanophytoplankton abundances and temperature (Rho $=-0.97, p$ value $<0.02, n=6$ ) and a significant positive relationship between nanophytoplanktons' and tintinnids' abundances (Rho $=0.97$, $p$ value $<0.02, n=6$ ). No other significant correlation between organisms' abundances and physico-chemical variables was found. 

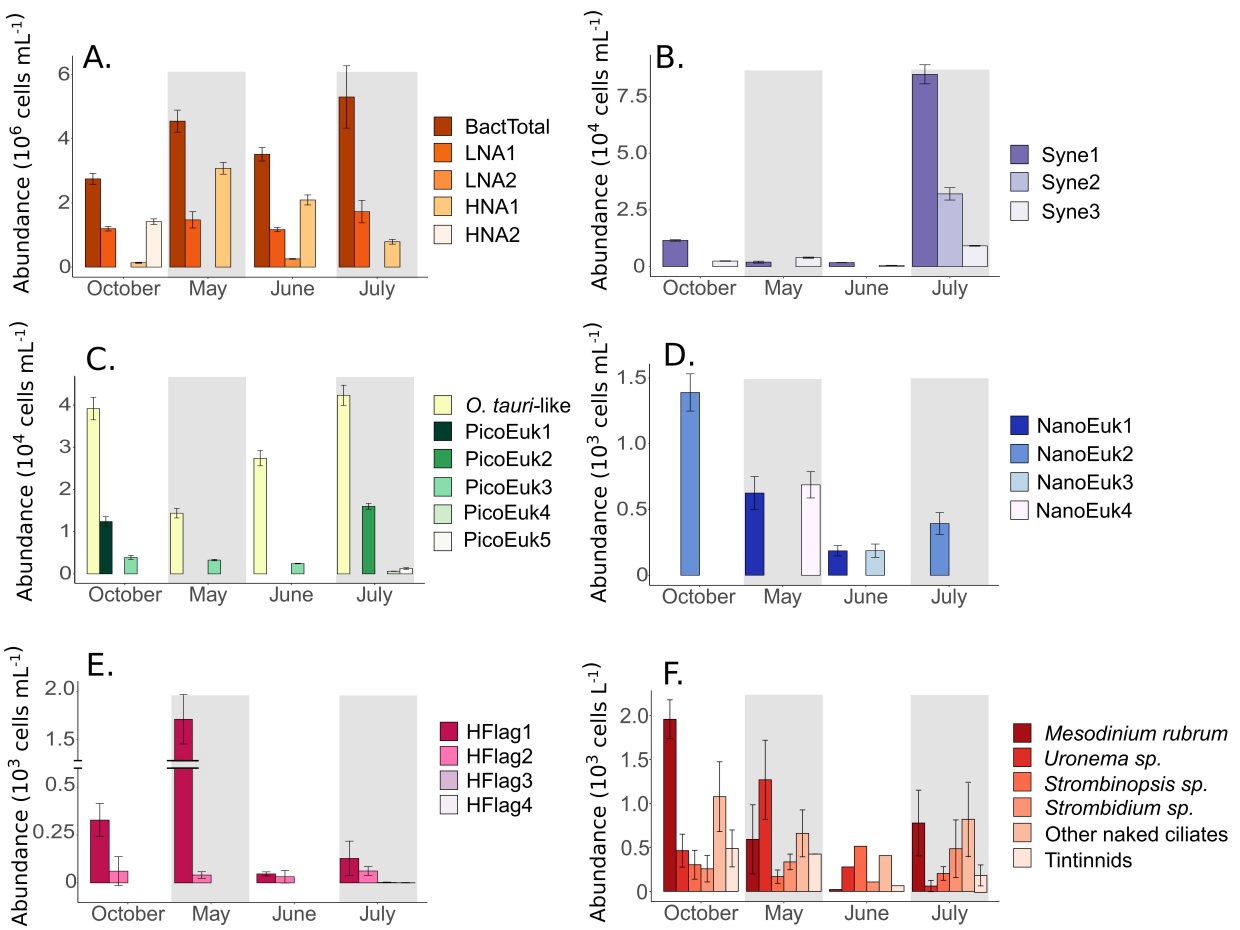

Figure 3. Abundances (cell $\mathrm{mL}^{-1}$ ) of different bacterial (LNA1, LNA2, HNA1, and HNA2) (A), cyanobacterial (Syne1, 2, and 3) (B), and eukaryotic pico- and nanophytoplankton groups (C,D), heterotrophic flagellate (HFlag1, HFlag2, HFlag3, and HFlag4 (E), and different groups of ciliates (F) encompassing Mesodinium rubrum, Uronema sp., Strombidinopsis sp., Strombidium sp., and other naked (aloricate) ciliates and tintinnids in October, May, June, and July. White and gray columns help to distinguish different months in the figures.

\subsection{Growth and Grazing Mortality Rates of MFW Components}

The growth rates of the HNA groups ranged between $1.63 \pm 0.15$ and $2.43 \pm 0.11$ day $^{-1}$ from October to July, reaching a minimum in May and a maximum in June. LNA1 and LNA2 had relatively constant growth rates, always above $1.16 \pm 0.13$ day $^{-1}$ (July), and reached maximal rates of $1.74 \pm 0.10$ day $^{-1}$ in June (Figure $4 \mathrm{~A}$ ). The growth rates of cyanobacteria ranged from $0.30 \pm 0.08$ to $1.09 \pm 0.07 \mathrm{day}^{-1}$, showing the highest rates in June when the water temperature was the highest (Figure 4C). However, despite its very high abundance, the $O$. tauri-like group showed relatively weak growth rates, reaching a maximum at $0.36 \pm 0.06$ day $^{-1}$ in July (Figure 4E). Maximum growth rates among eukaryotic picophytoplankton groups were observed in May within the PicoEuk3 group, reaching $1.05 \pm 0.05 \mathrm{day}^{-1}$. In this study, the highest growth rate among nanophytoplankton was found within the NanoEuk4 group in May $\left(0.98 \pm 0.09\right.$ day $\left.^{-1}\right)$, while the growth rates of the "other" nanophytoplankton groups reached a maximum of $0.32 \pm 0.17$ day $^{-1}$ (Figure 4G). Regarding each of the studied prokaryotic and eukaryotic phytoplankton groups independently, a positive trend was observed between their growth rates and water temperature; however, the trend was not significant, probably due to the reduced number of observations. In addition, no clear trends and no significant correlation were found between phytoplankton growth rates and nutrient concentration. 

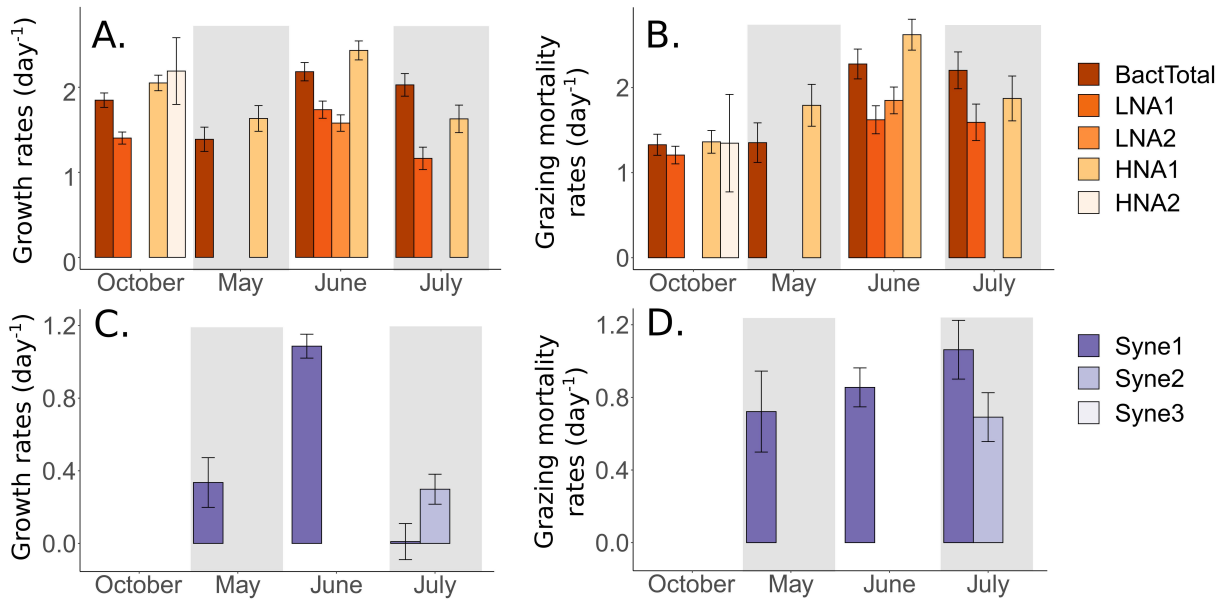

Syne1

$\square$ Syne2

Syne3
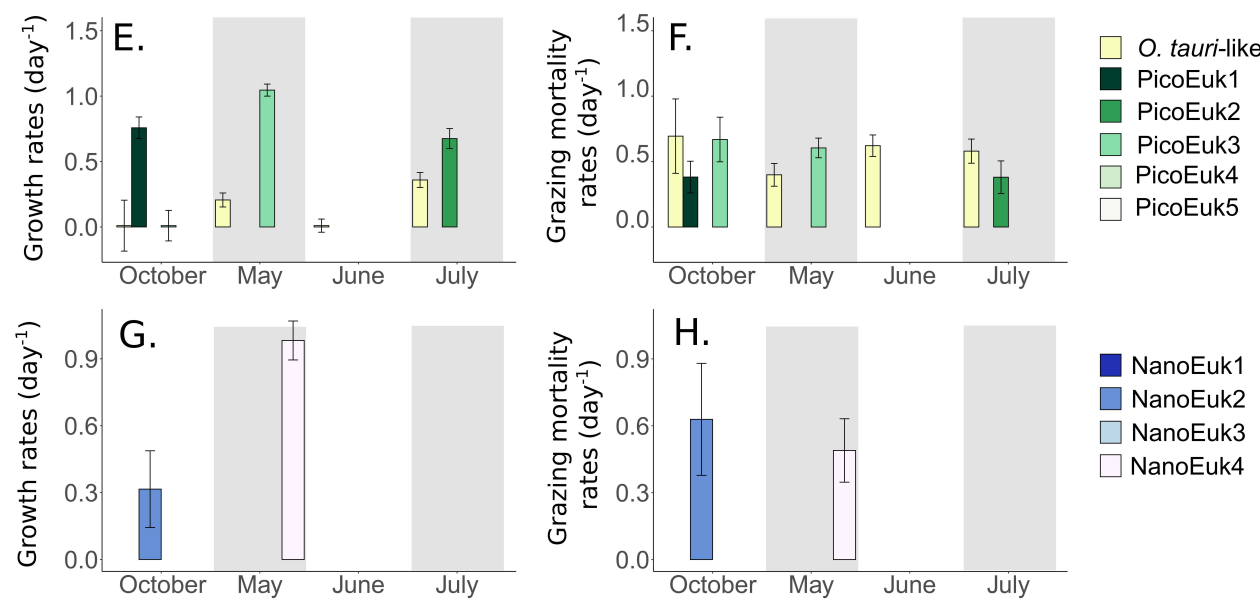

NanoEuk1

$\square$ NanoEuk2

$\square$ NanoEuk3

$\square$ NanoEuk4

Figure 4. Growth and grazing mortality rates $\left(\right.$ day $\left.^{-1}\right)$ of different bacterial $(\mathbf{A}, \mathbf{B})$, cyanobacterial $(\mathbf{C}, \mathbf{D})$, eukaryotic picophytoplankton $(\mathbf{E}, \mathbf{F})$, and eukaryotic nanophytoplankton groups $(\mathbf{G}, \mathbf{H})$. White and gray columns help to distinguish different months in the figures.

The grazing mortality rates of the total bacterial community were almost twice as high in the warmer months $\left(2.28 \pm 0.17\right.$ and $2.20 \pm 0.22$ day $^{-1}$ in June and July, respectively) than in the colder months $\left(1.33 \pm 0.12\right.$ and $1.35 \pm 0.23$ day $^{-1}$ in October and May, respectively; Figure 4B). Additionally, the HNA1 grazing mortality rates were almost twice those of the LNA1 group, reaching $2.62 \pm 0.18$ day $^{-1}$ in the warmer months. Within the cyanobacterial groups, the grazing mortality rates increased from October to July, reaching $1.06 \pm 0.16$ day $^{-1}$ for the Syne1 group (Figure 4D). Among eukaryotic picophytoplankton prey, O. tauri-like was grazed at the highest rates, at $0.69 \pm 0.28$ and $0.62 \pm 0.08$ day $^{-1}$ in October and June, respectively (Figure 4F). However, other eukaryotic picophytoplankton groups were also grazed at fairly high rates at the lowest water temperatures in October and May. A few significant grazing mortality rates were observed for the nanophytoplankton communities but did not show any particular pattern (Figure $4 \mathrm{H}$ ). There was a positive significant relationship ( $p$-value $<0.02$ ) between grazing mortality rates of bacterial groups and water temperature (Rho $=0.72, n=10$, Figure 5 ), and a positive but not significant relationship between cyanobacterial groups and water temperature. On the other hand, a reverse negative trend was observed for the relationships between the grazing mortality rates of eukaryotic pico- and nanophytoplankton and water temperature (Figure 5). The results of correlation analysis showed also negative correlations $(\mathrm{r}=-0.69, p$-value $<0.03)$ between grazing mortality rates of bacteria and abundances of (1) Mesodinium rubrum, (2) an undefined group of ciliates called "other naked ciliate", and (3) the whole tintinnids' community. No other significant correlation was found between other biological variables (abundances and/or rates). In addition, to determine whether there was any relationship 
between ciliate species' diversity and grazer activity, Shannon's diversity index was calculated for each of the experiments. Here, the objective was to assess the potential influence of the number of ciliate species on the grazing pressure. The relationships between the aloricate ciliate's Shannon diversity index and the grazing mortality rates of preys in the four dilution experiments did not show statistically significant differences, as the diversity indices were similar among the experiments (average $\mathrm{H}$ of $1.36 \pm 0.05$ ).

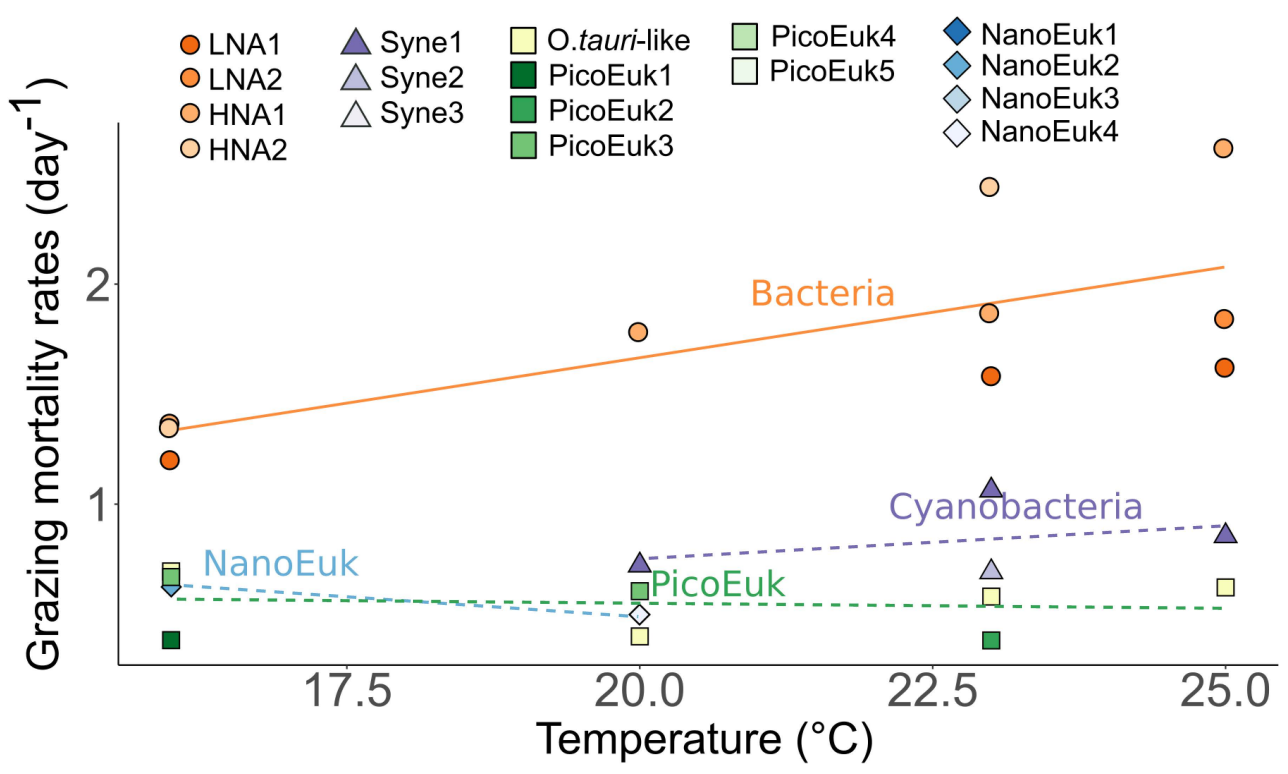

Figure 5. Grazing mortality rates of bacteria (shade of orange circles, full line indicates significant Spearman correlation with $p$-value $<0.05$ ), cyanobacteria (shade of purple triangles), PicoEuk (shade of green squares), and NanoEuk (shade of blue diamonds) for eukaryotic pico- and nanophytoplankton groups as a function of water temperature. Dashed lines indicate non-significant relationships.

\subsection{Cell Transfer through the MFW}

In the present study, 13 different bacterial and eukaryotic pico- and nanophytoplankton groups presented statistically significant growth and grazing mortality rates, allowing us to compute the g: $\mu$ ratios of these groups. The trend of the g: $\mu$ ratio for bacterial groups (1.0 on average) contrasted with that of other microorganisms, as that of bacteria remained close to a 1:1 ratio. Cyanobacteria showed the greatest g: $\mu$ ratio, reaching 2.32 in July for Syne2. The O. tauri-like group also showed high ratios during all experiments, reaching 1.93 in May. Regarding the g: $\mu$ ratio of each group obtained within the four experiments, the number of cells that were grazed and transferred to higher trophic levels was greater than the number of cells accumulated (g: $\mu>1$ ) for $60 \%$ of the cases (Figure 6). However, phytoplanktonic groups that were found more sporadically, such as eukaryotic pico- and nanophytoplankton groups that showed g: $\mu$ ratios below 1 , could accumulate in the lagoon, with the exception of a 1.99 ratio observed for NanoEuk2 in October (cf. Table S1; Supplementary Materials). 


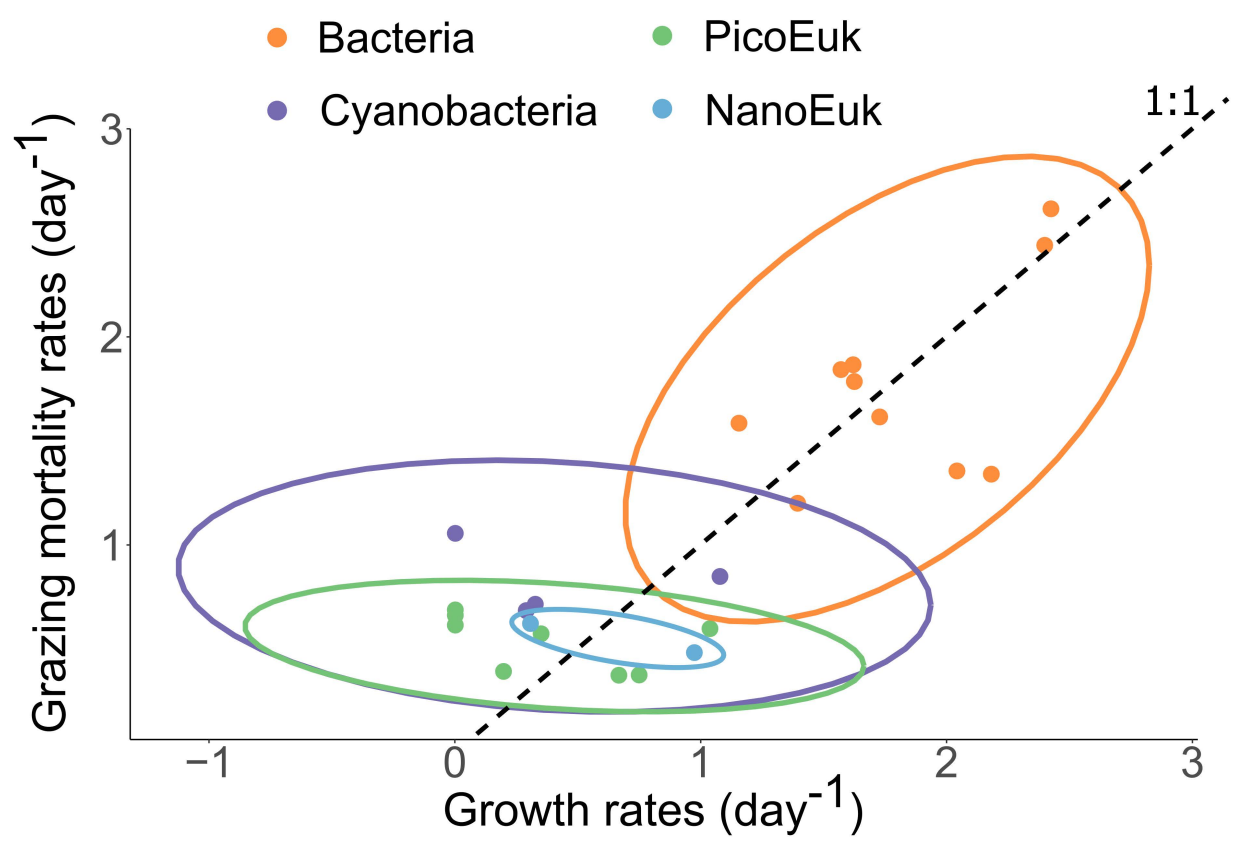

Figure 6. Representation of the g: $\mu$ ratios as grazing mortality rates relative to growth rates $\left(\right.$ day $\left.^{-1}\right)$ of the studied MFW components, including bacteria (orange), cyanobacteria (purple), PicoEuk (green), and NanoEuk (blue) for eukaryotic pico- and nanophytoplankton groups. The ellipses highlight the trend of the g: $\mu$ ratio for each type of microorganism. Black, dashed line represents the 1:1 ratio and allows quick vision of positive (accumulation of cells) or negative (decreasing of cell abundance) ratios of the planktonic groups.

\section{Discussion}

The present study relates a broad assemblage of microorganisms, from bacteria to pico- and nanophytoplankton groups and protists grazers such as heterotrophic flagellates and ciliates. The main objective of the present investigation was to assess changes in the functioning of the MFW components through estimations of their growth and grazing mortality rates in the Mediterranean coastal water of the Thau Lagoon encompassing different atmospheric seasonal conditions.

\subsection{Abundances of the MFW Components}

The bacterial abundances measured during this study were 5-10 times higher than those found previously in other studies in the northwestern Mediterranean open coastal waters or estuaries of the Adriatic Sea [17,47-49] but were similar to the abundances observed in mesocosm experiments in the Thau Lagoon [50-52]. The cyanobacterial abundances were generally quite low in the first three dilution experiments but strongly increased in July, in accordance with the positive relationship highlighted between cyanobacteria and the water temperature reported in the Thau Lagoon in studies of the MFW components [53-56]. Derolez et al. [56] underlined the relationships between the recent appearances (late 1990s) of the Synechococcus genus in the Thau Lagoon, especially in summer, and the trends of decreasing nutrients and increasing water temperature in the lagoon. In particular, the authors reported that the appearance of cyanobacteria could be linked to lagoon oligotrophication due to the reduction in the phosphorous supply from rivers combined with an increase in the mean water temperature of the lagoon over the last two decades. In the coastal Mediterranean Thau Lagoon, the picoeukaryote community comprises various species belonging to the order Mamiellales [57], the most abundant throughout the year being $O$. tauri, which was first discovered in the Thau Lagoon and is widely distributed in various oceanic and coastal environments [58]. In the present study, the O. tauri-like group was also detected, showing the highest observed abundances in the four experiments. 
Eukaryotic nanophytoplankton showed low abundances in almost every experiment, with the lowest abundance being in the warmer months when no significant rates were found. Indeed, nanophytoplankton were negatively correlated to water temperature, suggesting that they do not thrive in summer. However, there were low nutrient concentrations in all four dilution experiments, particularly concerning nitrogen and phosphorus. It could have limited Thau Lagoon nanophytoplankton growth during the incubation [52]. Moreover, a significant positive relationship between nanophytoplankton and tintinnids' abundances (Rho $=0.97, p$ value $<0.02, n=6$ ) was found and can explain the highest grazing mortality rate of the nanophytoplankton community observed in October, when tintinnids were the most abundant. The abundances of HFlag and ciliates determined in this study were comparable with those found by Vidussi et al. [50] and Mostajir et al. [51] in two mesocosm experiments carried out in the same lagoon in 2005 and 2006. However, lower abundances of HFlag and comparable abundances of ciliates were found in oligotrophic estuaries of the Adriatic Sea [49].

\subsection{Growth and Grazing Mortality Rates of MFW Components}

High bacterial growth rates were observed during the present study; notably, the highest growth rate of HNA1 $\left(2.43 \pm 0.11\right.$ day $\left.^{-1}\right)$ was up to 10 times higher than those reported in some Mediterranean areas $[17,47]$. However, these high bacterial growth rates were in the same range as those reported recently in a mesocosm study carried out in the same lagoon [52] or in a dilution experiment realized in estuarine water of the Adriatic Sea [19]. As reported by Pomeroy and Wiebe [3], both substrate availability and temperature control bacterial growth and bacterial abundances and nutrient concentrations were low in our four dilution experiments. The water temperatures recorded during this study, up to $25^{\circ} \mathrm{C}$, in conjunction with the low nutrient concentrations (especially $\mathrm{N}$ and $\mathrm{P})$ and enough organic matter availabilities could potentially support the high bacterial growth rates and abundances observed in this study, especially in June. In accordance with this, Šolić et al. [49] also pointed out the capacity of bacteria to reach high abundances in nutrient-limited conditions, notably phosphorus, in an estuary of the Adriatic Sea. It should be noted that in the present study, LNA had a relatively high growth rate, in agreement with that reported by Morán et al. [59], suggesting that LNA represents an active group of prokaryotes in the Thau Lagoon, especially during the warmer month as it was described for the Adriatic Sea by Šantić et al. [60]. As shown by Servais et al. [61], the HNA and LNA groups constituted an assemblage of several bacterial phylogenetic groups. Therefore, most of the high growth rates obtained in the present study could be those of dominant bacterial groups within the HNA and LNA groups, but further investigations are needed to identify the bacterial phylogenetic groups in the Thau Lagoon.

The cyanobacteria growth rates observed in this study $\left(0.30-1.09\right.$ day $\left.^{-1}\right)$ were within the range reported during dilution experiments made by Šolić et al. [19] with estuarine Mediterranean waters of the Adriatic Sea. The growth rates of eukaryotic pico- and nanophytoplankton measured in this study (from $0.21 \mathrm{day}^{-1}$ to $1.05 \pm 0.05 \mathrm{day}^{-1}$ ) were in the same range as those reported by Courboulès et al. [52] in a mesocosm experiment in the same area but lower than those observed by Bec et al. [57] in situ, who reported rates of $2.6 \mathrm{day}^{-1}$ for pico- and $2.9 \mathrm{day}^{-1}$ for nanophytoplankton. The higher growth rates reported in Bec et al. [57] were certainly due to the addition of nutrients in their dilution experiments relative to the present study, in which, deliberately, no nutrients were added. In fact, as explained above, one of the objectives of the present study was to determine more realistic growth rates of microorganisms under natural nutrient conditions. The high number of significant growth rates found in this study (more than $60 \%$ of the regressions) and the fact that Courboulès et al. [52] found that only the growth rate of one group of nanophytoplankton (large nanophytoplankton) among 10 studied microbial groups was significantly enhanced by the addition of nutrients suggests that, during the present experiment, there was a sufficient amount of nutrients and organic matter to support phytoplankton and bacterial growth. However, it cannot be excluded that, as nutrients 
were not added, growth rates of certain groups could be underestimated compared to those of large nanophytoplankton as reported by Courboulès et al. [52]. In this case, as it was shown by Calbet and Saiz [62], respective grazing mortality rates could be overestimated.

The grazing mortality rates presented here include the grazing activities due to all microzooplankton $\leq 200 \mu \mathrm{m}$, including not only heterotrophic flagellates and ciliates but also the phagotrophic activity of mixotrophs as well as those of other microzooplankton (e.g., copepod nauplii, rotifers, mollusk larvae). In the present study, mortality due to viral lysis was not studied as viruses were not removed in the dilutions' series. Therefore, only the nano- and micrograzing mortality rates of the prey were studied without considering the mortality due to viral lysis. Nevertheless, it is well known that viruses can cause up to $50 \%$ of bacterial mortality in the surface water [63-65] as bacteria are the most important host for viruses. In the Mediterranean coastal waters (Adriatic Sea), according to Šolić et al. [19], it seems that picoplankton mortality is of lesser extent, representing between 9 to $25 \%$. However, the last author underlined that, in some period of the year, during the warm months for example, a virus can also affect autotrophic picoplankton groups in the Adriatic Sea. In any case, the mortality rates presented in the present study indicate only those due to undistinguished nano- and microzooplankton grazers and do not include the mortality due to viruses. The most significant prey losses due to grazers in this study concerned bacterial groups. In general, grazing on the smallest prey, such as cyanobacteria and $O$. tauri-like prey, was quite high in every experiment, while we found almost no significant grazing mortality rates of larger prey, such as larger eukaryotic pico- or nanophytoplankton cells. This result suggested that in the Thau Lagoon small prey are of greater importance in the transfer of biomass by microzooplankton and the overall functioning of the MFW. Moreover, a significant positive relationship was found between bacteria grazing mortality rates and water temperature ( $p$-value $<0.02)$.

The main predators of bacteria could be HFlag [1,19,51], which showed the highest abundance in May, and small ciliates, which can ingest bacteria directly or indirectly through an intermediate grazer such as HFlag. The significant negative correlations found between the grazing mortality rates of bacteria and the abundances of Mesodinium rubrum, undefined group of ciliates, and the whole tintinnids' community could suggest a trophic cascade between the groups of ciliates predating on HFlag and, in this way, release the predation of HFlag on bacteria, thereby decreasing the bacterial grazing mortality. This trophic cascade was demonstrated in the same lagoon by Vidussi et al. [50].

The abundances of heterotrophic flagellates and the diversities and abundances of ciliates changed throughout the four experiments. The grazing mortality rates of eukaryotic prey remained stable, while those exerted on prokaryotic prey increased with increasing water temperature. These results are consistent with the experiments of Šolić et al. [19] showing an increase in the grazing mortality rates of prokaryotic preys in the warmer month. An ecological explanation for this result could be, for example, the recognized ability of ciliates to switch from one prey to another when several types of prey are available and when the abundance of one type of prey decreases [66]. Indeed, in the present study, the ciliate community was dominated by Mesodinium rubrum, Strombidinopsis sp., Strombidium sp., and Uronema sp. Uronema sp. is known to be a non-selective predator, selecting neither for size nor for cell surface properties, while Strombidium sp. is slightly more selective [67]. Moreover, Mesodinium rubrum, a mixotrophic organism [68,69], showed high abundances, especially in October and July. Among mixotrophs, small mixotrophic algae (i.e., small eukaryotic phytoflagellates) may also be responsible for a significant portion of grazing on bacteria in marine systems [70-72], as well as mixotrophic and heterotrophic dinoflagellates $[73,74]$. Additionally, some of the observed predators could graze upon many more types of prey than others during an experiment relative to other predators. Surprisingly, in June, the most important bacterial grazing mortality rate was observed despite minimum abundances of studied predators, such as aloricate ciliates, tintinnids, and heterotrophic flagellates. It could suggest that some of them, such as Strombidinopsis, which was observed at its maximum abundance in June, could have exerted high predation 
rates on the prey, including bacteria, either directly or indirectly. The maximum tintinnid abundances during this study were observed in May and were concomitant with the maximum abundances of the small HFlag1, suggesting predation by tintinnids on the predators of HFlag, resulting in high HF abundances.

Although the main objective of the present study was not to find the environmental variables that may influence grazing mortality or growth rates of microorganisms, it is, however, worth reporting interesting results highlighting (1) positive relationships between the water temperature and the grazing mortality rates of the bacterial groups and (2) a nonsignificant positive trend for cyanobacterial groups in the four experiments. The highest grazing mortality rates, specifically of prokaryotic prey, were observed during the warmer months in June and July, suggesting a positive relationship among grazing activity, water temperature, and low nutrient concentrations (especially phosphorus) in accordance with the previous studies $[5,19,75]$. In contrast, regarding eukaryotic picophytoplankton and especially nanophytoplankton, a reverse trend was observed, with rather lower grazing mortality rates observed in warmer waters. This result is consistent with the review by Rose and Caron [75], which suggested that phytoplankton blooms occurred in cold water worldwide because protozoan grazers are unable to grow correctly at these lower temperatures, resulting in low grazing pressures on phytoplankton. These authors observed that the difference in growth rates between phytoplankton prey and protozoan predators decreased when the temperature increased, allowing the efficient grazing on phytoplankton by predators. The relationships between the prokaryotic grazing mortality rates and water temperature found in this study also seem to indicate that grazing processes in the Thau Lagoon were more strongly temperature dependent than growth processes, as has been suggested in other studies [76,77]. Other studies have also reported that temperature shows no linear relationship with grazing mortality rates but also depends on the behaviors of individual predators [78,79]. Finally, according to recent studies, temperature appeared to be a key parameter in structuring the plankton community in the Thau Lagoon $[53,55]$.

\subsection{The Fate of the MFW Components: Accumulation or Transfer?}

The simultaneous study of the majority of the MFW components makes it possible to compare the growth and grazing mortality rates of these components, providing useful information on their fate throughout the food web by studying the ratio between the grazing mortality and growth rates of each microorganism. These comparative results clearly show that, among all studied microorganisms, bacterial groups are distinguishable from phytoplankton groups, as their growth and grazing mortality rates in all seasons are higher than those of phytoplankton. This fact led to the efficient and strong transfer of bacterial groups to the microzooplankton compartment (up to 2.43 day $^{-1}$ and 2.62 day $^{-1}$ for HNA1 in June for $\mu$ and $g$, respectively). All bacterial groups seem to be actively controlled by their predators, as their grazing mortality rates are always higher than their growth rates except in October, when the water temperature is lower than in other months. In fact, the ratios increased with temperature during these experiments, indicating the top-down control of the bacterial population dynamics linked to temperature. In all experiments, a g: $\mu$ ratio near 1 indicated a close coupling between bacteria and predators in the Thau Lagoon, as reported in previous studies for other ecosystems [80]. In comparison with the bacterial (HNA and LNA) growth and grazing mortality rates measured by Scharek and Latasa [17] in the northwestern Mediterranean Sea, our results showed an opposite trend for the closest comparable stations. In the open sea, for both the LNA and HNA groups, these authors found ratios that ranged between 0.41 and 0.70 at the nearest site to the Thau Lagoon. These $<1$ ratios indicated an accumulation of bacterial cells, which was not the case in the results of the present study, as detailed before. Additionally, the ranges of the growth rates of phytoplankton groups in each month and during the seasons observed in the present study were generally higher than those of their grazing mortality rates, which underlines that phytoplankton groups were less controlled by predators than were bacterial groups. Agusti et al. [81] studied phytoplankton growth and grazing mortality rates in open 
waters of the Mediterranean Sea using bulk chlorophyll a, and, unlike bacteria, obtained $\mathrm{g}: \mu$ ratios $>1$ (g: $\mu=1.23)$, indicating the active control of bulk phytoplankton by predators. Obviously, bulk phytoplankton measurements indicate the growth and grazing mortality rates of the whole phytoplankton community, and further comparisons with specific rates as observed in the present study should be considered carefully. However, this inversion of the patterns observed between bacteria and phytoplankton, as observed between the present study and previous open-sea observations, could indicate an effect of the ecosystem richness, reflecting oligotrophic conditions in open sea and mesotrophic conditions in the lagoon, on the efficiency and nature of the cell transfer through the MFW. Finally, there was a positive relationship observed between water temperature and the in situ growth rates of all studied groups encompassing bacteria and pico- and nanophytoplankton. This result is in agreement with the results of several studies reporting positive correlations between temperature and phytoplankton or bacterial growth rates [3,5,82-84]. This positive relationship was also found between the in situ grazing mortality rates of prokaryotic microorganisms and water temperature. These later observations underlined that in summer, when the water temperature was high and the nutrient concentration was low, the MFW of the Thau Lagoon was turned towards the transfer of small prokaryotic cell production rather than larger eukaryotic prey throughout microzooplankton predators.

In conclusion, this study reported poorly documented estimates of fundamental biological processes such as growth and mortality by predation of 12 cytometric groups of planktonic microorganisms measured in situ in a Mediterranean coastal lagoon in different atmospheric seasons encompassing various environmental conditions. Additionally, this study demonstrated that the simultaneous studies of the growth and grazing mortality rates of all microbial components together at the single-cell scale provide useful information about the fate of each specific microbial group throughout the MFW. This kind of information cannot be obtained by bulk measurements, such as chlorophyll a concentration or total bacterial abundance measurements, which estimate the average growth and grazing mortality rates of several groups. This degree of functional resolution allows a better understanding of the MFW structure and functioning.

Supplementary Materials: The following supporting information can be downloaded at: https: / / www.mdpi.com/article/10.3390/d14030186/s1, Table S1: Significant growth $\left(\mu\right.$, day $^{-1} \pm$ S. D) and grazing mortality rates $\left(\mathrm{g}\right.$, day ${ }^{-1} \pm \mathrm{S}$. D) of microbial components observed during the four dilution experiments in October 2008 and May, June and July 2009 in the Thau Lagoon. The g: $\mu$ ratio is also noted if available. N.A indicates that the data are not available.

Author Contributions: D.P.: conceptualization, methodology, validation, formal analysis, investigation, writing - original draft, and writing-review and editing. J.C.: software, formal analysis, writing-review and editing, and visualization. C.R.: investigation. S.M.: data curation and investigation. R.P.: investigation. F.V.: conceptualization, methodology, validation, writing-review and editing, supervision, project administration, and funding acquisition. B.M.: conceptualization, methodology, validation, writing-review and editing, supervision, project administration, and funding acquisition. All authors have read and agreed to the published version of the manuscript.

Funding: This research received no external funding.

Institutional Review Board Statement: Not applicable.

Data Availability Statement: All data are available in the text.

Acknowledgments: D.P. was supported by a national scientific Ph.D. fellowship provided by the French Ministry of Education and Research. We are grateful to Camille Albouy for his advice on statistical analyses and Christophe Vasseur, Emilie Le Floc'h, and Eric Fouilland for their assistance with the experiments.

Conflicts of Interest: The authors declare that they have no known competing financial interest or personal relationships that could have appeared to influence the work reported in this paper. 


\section{References}

1. Azam, F.; Fenchel, T.; Field, J.G.; Gray, J.S.; Meyer-Reil, L.A.; Thingstad, F. The Ecological Role of Water-Column Microbes in the Sea. Mar. Ecol. Prog. Ser. 1983, 10, 257-263. [CrossRef]

2. Sherr, B.F.; Sherr, E.B. Marine microbes: An overview. In Microbial Ecology of the Oceans; Kirchman, D., Ed.; Wiley-Liss: New York, NY, USA, 2000; pp. 13-46.

3. Pomeroy, L.R.; Wiebe, W.J. Temperature and substrates as interactive limiting factors for marine heterotrophic bacteria. Aquat. Microb. Ecol. 2001, 23, 187-204. [CrossRef]

4. Brown, J.H.; Gillooly, J.F.; Allen, A.P.; Savage, V.M.; West, G.B. Toward a metabolic theory of ecology. Ecology 2004, 85, 1771-1789. [CrossRef]

5. Chen, B.; Laws, E.A. Is there a difference of temperature sensitivity between marine phytoplankton and heterotrophs? Limnol. Oceanogr. 2017, 62, 806-817. [CrossRef]

6. Sherr, E.B.; Sherr, B.F. Significance of predation by protists in aquatic microbial food webs. Antonie Van Leeuwenhoek 2002, 81, 293-308. [CrossRef]

7. Calbet, A.; Landry, M.R. Phytoplankton growth, microzooplankton grazing, and carbon cycling in marine systems. Limnol. Oceanogr. 2004, 49, 51-57. [CrossRef]

8. Rublee, P.; Gallegos, C. Use of fluorescently labelled algae (FLA) to estimate microzooplankton grazing. Mar. Ecol. Prog. Ser. 1989, 51, 221-227. [CrossRef]

9. Landry, M.R.; Hassett, R.P. Estimating the grazing impact of marine micro-zooplankton. Mar. Biol. 1982, 67, 283-288. [CrossRef]

10. Vrba, J.; Simek, K.; Nedoma, J.; Hartman, P. MUF-P-N-acetylglucosaminide hydrolysis by a high affinity enzyme, a putative marker of protozoan bacterivory. Appl. Environ. Microbiol. 1993, 59, 3091-3101. [CrossRef]

11. Fuhrman, J.A.; McManus, G.B. Do Bacteria-Sized Marine Eukaryotes Consume Significant Bacterial Production? Science 1984, 224, 1257-1260. [CrossRef]

12. Sherr, B.F.; Sherr, E.B.; Andrew, T.L.; Fallon, R.D.; Newell, S.Y. Trophic interactions between protozoa and bacterioplankton in estuarine water analyzed with selective metabolic inhibitors. Mar. Ecol.-Prog. Ser. 1986, 32, 169-180. [CrossRef]

13. Landry, M.R.; Kirshtein, J.; Constantinou, J. A refined dilution technique for measuring the community grazing impact of microzooplankton, with experimental tests in the central equatorial Pacific. Mar. Ecol. Prog. Ser. 1995, 120, 53-63. [CrossRef]

14. Tsai, A.-Y.; Gong, G.-C.; Sanders, R.; Chiang, K.-P.; Chao, C.-F. Heterotrophic bacterial and Synechococcus spp. Growth and mortality along the inshore-offshore in the East China Sea in summer. J. Oceanogr. 2012, 68, 151-162. [CrossRef]

15. Staniewski, M.A.; Short, C.M.; Short, S.M. Contrasting Community versus Population-Based Estimates of Grazing and VirusInduced Mortality of Phytoplankton. Microb. Ecol. 2012, 64, 25-38. [CrossRef] [PubMed]

16. Chen, B.; Landry, M.R.; Huang, B.; Liu, H. Does warming enhance the effect of microzooplankton grazing on marine phytoplankton in the ocean? Limnol. Oceanogr. 2012, 57, 519-526. [CrossRef]

17. Scharek, R.; Latasa, M. Growth, grazing and carbon flux of high and low nucleic acid bacteria differ in surface and deep chlorophyll maximum layers in the NW Mediterranean Sea. Aquat. Microb. Ecol. 2007, 46, 153-161. [CrossRef]

18. Ferrera, I.; Gasol, J.M.; Marta, S.; Hojerova, E.; Koblizek, M. Comparison of growth rates of aerobic anoxygenic phototrophic bacteria and other bacterioplankton groups in coastal Mediterranean waters. Appl. Environ. Microbiol. 2011, 77, 7451-7458. [CrossRef]

19. Šolić, M.; Šantić, D.; Šestanović, S.; Bojanić, N.; Ordulj, M.; Jozić, S.; Vrdoljak, A. The effect of temperature increase on microbial carbon fluxes in the Adriatic Sea: An experimental approach. FEMS Microbiol. Ecol. 2018, 94, fiy169. [CrossRef]

20. Šolić, M.; Šantić, D.; Šestanović, S.; Bojanić, N.; Jozić, S.; Ordulj, M.; Tomaš, A.V.; Kušpilić, G. Changes in the trophic path-ways within the microbial food web in the global warming scenario: An experimental study in the Adriatic Sea. Microorganisms 2020, 8, 510. [CrossRef]

21. Treguer, P.; Le Corre, P. Manuel d'Analyse des sels Nutritifs Dans l'Eau de mer: Utilisation de l'Autoanalyzer II Technicon, 2nd ed.; Laboratoire d'Océanographie Chimique, Université de Bretagne Occidentale: Brest, France, 1975; 110p.

22. Pecqueur, D.; Vidussi, F.; Fouilland, E.; Le Floc'h, E.; Mas, S.; Roques, C.; Salles, C.; Tournoud, M.G.; Mostajir, B. Dynamics of microbial planktonic food web components during a river flash flood in a Mediterranean coastal lagoon. Hydrobiologia 2011, 673, 13-27. [CrossRef]

23. Marie, D.; Partensky, F.; Jacquet, S.; Vaulot, D. Enumeration and cell cycle analysis of natural populations of marine picoplankton by flow cytometry using the nucleic acid stain SYBR Green, I. Appl. Environ. Microbiol. 1997, 63, 186-193. [CrossRef] [PubMed]

24. Marie, D.; Partensky, F.; Vaulot, D.; Brussaard, C. Enumeration of Phytoplankton, Bacteria, and Viruses in Marine Samples. Curr Protoc. Cytom. 1999, 10, 11.11.1-11.11.15. [CrossRef] [PubMed]

25. Gasol, J.M.; Zweifel, U.L.; Peters, F.; Fuhrman, J.A.; Hagström, A. Significance of Size and Nucleic Acid Content Heterogeneity as Measured by Flow Cytometry in Natural Planktonic Bacteria. Appl. Environ. Microbiol. 1999, 65, 4475-4483. [CrossRef] [PubMed]

26. Jochem, F.J.; Lavrentyev, P.J.; First, M.R. Growth and grazing rates of bacteria groups with different apparent DNA content in the Gulf of Mexico. Mar. Biol. 2004, 145, 1213-1225. [CrossRef]

27. Morán, X.A.G.; Bode, A.; Suárez, L.Á.; Nogueira, E. Assessing the relevance of nucleic acid content as an indicator of marine bacterial activity. Aquat. Microb. Ecol. 2007, 46, 141-152. [CrossRef]

28. Sherr, E.B.; Caron, D.A.; Sherr, B.F. Staining of heterotrophic protists for visualization via epifluorescence microscopy. In Handbook of Methods in Aquatic Microbial Ecology; Kemp, P.F., Ed.; Lewis Publishers: Boca Raton, FL, USA, 1993; pp. $213-229$. 
29. Kofoid, C.A.; Campbell, A.S. The Ciliata: The Tintinnoinea; Bulletin of the Museum of Comparative Zoology at Harvard College: Boston, MA, USA, 1939; pp. 1-473.

30. Grassé, P.P. Traité de Zoologie; Masson: Paris, France, 1952; Volume 1.

31. Bick, H. (Ed.) Ciliated Protozoa; World Health Organization: Geneva, Switzerland, 1972.

32. Kudo, R.R. Protozoology, 5th ed.; Charles, C. Thomas Publisher: Springfield, IL, USA, 1977.

33. Corliss, J.O. The Ciliate Protozoa: Characterisation, Classification and Guide to the Literature, 2nd ed.; Pergamon: Oxford, UK, 1979.

34. Maeda, M.; Carey, P.G. An Illustrated Guide to the Species of the Family Strombidiidae (Oligotrichida, Ciliophora), Free Swimming Protozoa Common in the Aquatic Environment; Bulletin of the Ocean Research Institute University of Tokyo: Tokyo, Japan, 1985.

35. Carey, P.G. Marine Interstitial Ciliates; Chapman and Hall: London, UK, 1992.

36. Chrétiennot-Dinet, M.J.; Billard, C.; Sournia, A. Chlorarachniophycées, Chlorophycées, Chrysophycées, Cryptophycées, Euglénophycées, Eustigmatophycées, Prasinophycées, Prymnésiophycées, Rhodophycées et Tribophycées; Editions du Centre National de la Recherche Scientifique: Paris, France, 1990.

37. Paulmier, G. Tintinnides (Ciliophora, Oligotrichida, Tintinnina) de l'Atlantique Boréal, de l'Océan Indien et de Quelques Mers Adjacentes: Méditerranée, Mer Caraibe, Mer Rouge. Inventaire et Distribution. Observations Basées sur les Loricas. 1997. Available online: https:/ / archimer.ifremer.fr/doc/00424/53609/ (accessed on 25 January 2022).

38. Sokal, R.R.; Rohlf, F.J. Biometry WH Freeman and Co San Francisco. Biometry, 2nd ed.; WH Freeman and Co.: San Francisco, CA, USA, 1981.

39. Landry, M.R.; Calbet, A. Microzooplankton production in the oceans. ICES J. Mar. Sci. 2004, 61, 501-507. [CrossRef]

40. Gasol, J.M.; del Giorgio, P.A. Using flow cytometry for counting natural planktonic bacteria and understanding the structure of planktonic bacterial communities. Sci. Mar. 2000, 64, 197-224. [CrossRef]

41. LeBaron, P.; Servais, P.; Agogué, H.; Courties, C.; Joux, F. Does the High Nucleic Acid Content of Individual Bacterial Cells Allow Us to Discriminate between Active Cells and Inactive Cells in Aquatic Systems? Appl. Environ. Microbiol. 2001, 67, 1775-1782. [CrossRef]

42. Zubkov, M.V.; Fuchs, B.M.; Archer, S.D.; Kiene, R.P.; Amann, R.; Burkill, P.H. Linking the composition of bacterioplankton to rapid turnover of dissolved dimethylsulphoniopropionate in an algal bloom in the North Sea. Environ. Microb. 2001, 3, 304-311. [CrossRef]

43. Zubkov, M.V.; Fuchs, B.M.; Burkill, P.H.; Amann, R. Comparison of Cellular and Biomass Specific Activities of Dominant Bacterioplankton Groups in Stratified Waters of the Celtic Sea. Appl. Environ. Microbiol. 2001, 67, 5210-5218. [CrossRef]

44. Courties, C.; Vaquer, A.; Troussellier, M.; Lautier, J.; Chrétiennot-Dinet, M.J.; Neveux, J.; Machado, C.; Claustre, H. Smallest eukaryotic organism. Nature 1994, 370, 255. [CrossRef]

45. Chrétiennot-Dinet, M.-J.; Courties, C.; Vaquer, A.; Neveux, J.; Claustre, H.; Lautier, J.; Machado, M.C. A new marine picoeucaryote: Ostreococcus tauri gen. et sp. nov. (Chlorophyta, Prasinophyceae). Phycologia 1995, 34, 285-292. [CrossRef]

46. Fouilland, E.; Descolas-Gros, C.; Courties, C.; Collos, Y.; Vaquer, A.; Gasc, A. Productivity and Growth of a Natural Population of the Smallest Free-Living Eukaryote under Nitrogen Deficiency and Sufficiency. Microb. Ecol. 2004, 48, 103-110. [CrossRef] [PubMed]

47. Vaqué, D.; Casamayor, E.O.; Gasol, J.M. Dynamics of whole community bacterial production and grazing losses related to changes in the proportion of bacteria with different DNA- content. Aquat. Microb. Ecol. 2001, 25, 163-177. [CrossRef]

48. Alonso-Sáez, L.; Vázquez-Domínguez, E.; Cardelus, C.; Pinhassi, J.; Sala, M.M.; Lekunberri, I.; Balagué, V.; Vila-Costa, M.; Unrein, F.; Massana, R.; et al. Factors controlling the year-round variability in carbon flux through bacteria in a coastal marine system. Ecosystems 2018, 11, 397-409. [CrossRef]

49. Šolić, M.; Krstulović, N.; Šantić, D.; Šestanović, S.; Ordulj, M.; Bojanić, N.; Kušpilić, G. Structure of microbial communities in phosphorus-limited estuaries along the eastern Adriatic coast. J. Mar. Biol. Assoc. UK 2015, 95, 1565-1578. [CrossRef]

50. Vidussi, F.; Mostajir, B.; Fouilland, E.; Le Floc'h, E.; Nouguier, J.; Roques, C.; Got, P.; Thibault-Botha, D.; Bouvier, T.; Troussellier, M. Effects of experimental warming and increased ultraviolet B radiation on the Mediterranean plankton food web. Limnol Oceanogr 2011, 56, 206-218. [CrossRef]

51. Mostajir, B.; Roques, C.; Bouvier, C.; Bouvier, T.; Fouilland, É.; Got, P.; Le Floc'H, E.; Nouguier, J.; Mas, S.; Sempéré, R.; et al. Microbial food web structural and functional responses to oyster and fish as top predators. Mar. Ecol. Prog. Ser. 2015, 535, 11-27. [CrossRef]

52. Courboulès, J.; Vidussi, F.; Soulié, T.; Mas, S.; Pecqueur, D.; Mostajir, B. Effects of experimental warming on small phytoplankton, bacteria and viruses in autumn in the Mediterranean coastal Thau Lagoon. Aquat. Ecol. 2021, 55, 647-666. [CrossRef]

53. Trombetta, T.; Vidussi, F.; Mas, S.; Parin, D.; Simier, M.; Mostajir, B. Water temperature drives phytoplankton blooms in coastal waters. PLoS ONE 2019, 14, e0214933. [CrossRef]

54. Trombetta, T.; Vidussi, F.; Roques, C.; Scotti, M.; Mostajir, B. Marine Microbial Food Web Networks During Phytoplankton Bloom and Non-bloom Periods: Warming Favors Smaller Organism Interactions and Intensifies Trophic Cascade. Front. Microbiol. 2020, 11, 2657. [CrossRef] [PubMed]

55. Trombetta, T.; Vidussi, F.; Roques, C.; Mas, S.; Scotti, M.; Mostajir, B. Co-occurrence networks reveal the central role of temperature in structuring the plankton community of the Thau Lagoon. Sci. Rep. 2021, 11, 17675. [CrossRef]

56. Derolez, V.; Soudant, D.; Malet, N.; Chiantella, C.; Richard, M.; Abadie, E.; Aliaume, C.; Bec, B. Two decades of oligotrophica-tion: Evidence for a phytoplankton community shift in the coastal lagoon of Thau (Mediterranean Sea, France). Estuar. Coast. Shelf Sci. 2020, 241, 106810. [CrossRef] 
57. Bec, B.; Husseini-Ratrema, J.; Collos, Y.; Souchu, P.; Vaquer, A. Phytoplankton seasonal dynamics in a Mediterranean coastal lagoon: Emphasis on the picoeukaryote community. J. Plankton Res. 2005, 27, 881-894. [CrossRef]

58. Guillou, L.; Eikrem, W.; Chrétiennot-Dinet, M.-J.; Le Gall, F.; Massana, R.; Romari, K.; Pedrós-Alió, C.; Vaulot, D. Diversity of Picoplanktonic Prasinophytes Assessed by Direct Nuclear SSU rDNA Sequencing of Environmental Samples and Novel Isolates Retrieved from Oceanic and Coastal Marine Ecosystems. Protist 2004, 155, 193-214. [CrossRef]

59. Morán, X.A.G.; Ducklow, H.W.; Erickson, M. Single-cell physiological structure and growth rates of heterotrophic bacteria in a temperate estuary (Waquoit Bay, Massachusetts). Limnol. Oceanogr. 2010, 56, 37-48. [CrossRef]

60. Šantić, D.; Krstulović, N.; Šolić, M.; Ordulj, M.; Kušpilić, G. Dynamics of prokaryotic picoplankton community in the central and southern Adriatic Sea (Croatia). Helgol. Mar. Res. 2012, 67, 471-481. [CrossRef]

61. Servais, P.; Casamayor, E.O.; Courties, C.; Catala, P.; Parthuisot, N.; LeBaron, P. Activity and diversity of bacterial cells with high and low nucleic acid content. Aquat. Microb. Ecol. 2003, 33, 41-51. [CrossRef]

62. Calbet, A.; Saiz, E. How much is enough for nutrients in microzooplankton dilution grazing experiments? J. Plankton Res. 2017, 40, 109-117. [CrossRef]

63. Fuhrman, J.A. Marine viruses and their biogeochemical and ecological effects. Nature 1999, 399, 541-548. [CrossRef]

64. Baudoux, A.C.; Veldhuis, M.J.W.; Noordeloos, A.A.M.; Van Noort, G.; Brussaard, C.P.D. Estimates of virus vs. grazing induced mortality of picophytoplankton in the North Sea during summer. Aquat. Microb. Ecol. 2008, 52, 69-82. [CrossRef]

65. Danovaro, R.; Corinaldesi, C.; Dell'Anno, A.; Fuhrman, J.A.; Middelburg, J.J.; Noble, R.T.; Suttle, C.A. Marine viruses and global climate change. FEMS Microbiol. Rev. 2011, 35, 993-1034. [CrossRef] [PubMed]

66. Rassoulzadegan, F. Dependence of grazing rate, gross growth efficiency and food size range on temperature in a pelagic oligotrichous ciliate Lohmanniella spiralis Leeg., fed on naturally occurring particulate matter. Ann. l'Institut Oceanogr. Paris Nouv. Ser. 1982, 58, 177-184.

67. Christaki, U.; Dolan, J.; Pelegri, S.; Rassoulzadegan, F. Consumption of picoplankton-size particles by marine ciliates: Effects of physiological state of the ciliate and particle quality. Limnol. Oceanogr. 1998, 43, 458-464. [CrossRef]

68. Hansen, P.J.; Moldrup, M.; Tarangkoon, W.; Garcia-Cuetos, L.; Moestrup, Ø. Direct evidence for symbiont seques-tration in the marine red tide ciliate Mesodinium rubrum. Aquat. Microb. Ecol. 2012, 66, 63-75. [CrossRef]

69. Seong, K.A.; Myung, G.; Jeong, H.J.; Yih, W.; Kim, H.S.; Jo, H.J.; Park, J.Y.; Du Yoo, Y. Ingestion rate and grazing impact by the mixotrophic ciliate Mesodinium rubrum on natural populations of marine heterotrophic bacteria in the coastal waters of Korea ALGAE 2017, 32, 47-55. [CrossRef]

70. Unrein, F.; Massana, R.; Alonso-Sáez, L.; Gasol, J.M. Significant year-round effect of small mixotrophic flagellates on bacterioplankton in an oligotrophic coastal system. Limnol. Oceanogr. 2007, 52, 456-469. [CrossRef]

71. Zubkov, M.V.; Tarran, G.A. High bacterivory by the smallest phytoplankton in the North Atlantic Ocean. Nature 2008, 455, 224-226. [CrossRef]

72. Hartmann, M.; Grob, C.; Tarran, G.A.; Martin, A.P.; Burkill, P.H.; Scanlan, D.; Zubkov, M.V. Mixotrophic basis of Atlantic oligotrophic ecosystems. Proc. Natl. Acad. Sci. USA 2012, 109, 5756-5760. [CrossRef]

73. Stoecker, D.K. Mixotrophy among Dinoflagellates. J. Eukaryot. Microbiol. 1999, 46, 397-401. [CrossRef]

74. Jeong, H.J.; Du Yoo, Y.; Kim, J.S.; Seong, K.A.; Kang, N.S.; Kim, T.H. Growth, feeding and ecological roles of the mixotrophic and heterotrophic dinoflagellates in marine planktonic food webs. Ocean Sci. J. 2010, 45, 65-91. [CrossRef]

75. Rose, J.M.; Caron, D.A. Does low temperature constrain the growth rates of heterotrophic protists? Evidence and implications for algal blooms in cold waters. Limnol. Oceanogr. 2007, 52, 886-895. [CrossRef]

76. Bissinger, J.E.; Montagnes, D.J.S.; Sharples, J.; Atkinson, D. Predicting marine phytoplankton maximum growth rates from temperature: Improving on the Eppley curve using quantile regression. Limnol. Oceanogr. 2008, 53, 487-493. [CrossRef]

77. Zhou, L.; Tan, Y.; Huang, L.; Li, G. Does microzooplankton grazing contribute to the picophytoplankton dominance in subtropical and tropical oligotrophic waters? Acta Ecol. Sin. 2015, 35, 29-38. [CrossRef]

78. Menden-Deuer, S.; Lawrence, C.; Franzè, G. Herbivorous protist growth and grazing rates at in situ and artificially elevated temperatures during an Arctic phytoplankton spring bloom. PeerJ 2018, 6, e5264. [CrossRef]

79. Anderson, S.; Harvey, E.L. Seasonal Variability and Drivers of Microzooplankton Grazing and Phytoplankton Growth in a Subtropical Estuary. Front. Mar. Sci. 2019, 6, 174. [CrossRef]

80. Jürgens, K.; Gasol, J.M.; Vaqué, D. Bacteria-flagellate coupling in microcosm experiments in the Central Atlantic Ocean. J. Exp. Mar. Biol. Ecol. 2000, 245, 127-147. [CrossRef]

81. Agusti, S.; Satta, M.P.; Mura, M.P.; Benavent, E. Dissolved esterase activity as a tracer of phytoplankton lysis: Evidence of high phytoplankton lysis rates in the northwestern Mediterranean. Limnol. Oceanogr. 1998, 43, 1836-1849. [CrossRef]

82. Eppley, R.W. Temperature and phytoplankton growth in the sea. Fish. Bull. 1972, 70, 1063-1085.

83. White, P.A.; Kalff, J.; Rasmussen, J.B.; Gasol, J.M. The effect of temperature and algal biomass on bacterial production and specific growth rate in freshwater and marine habitats. Microb. Ecol. 1991, 21, 99-118. [CrossRef]

84. Huete-Stauffer, T.M.; Arandia-Gorostidi, N.; Díaz-Pérez, L.; Morán, X.A.G. Temperature dependences of growth rates and carrying capacities of marine bacteria depart from metabolic theoretical predictions. FEMS Microbiol. Ecol. 2015, 91 , fiv111. [CrossRef] [PubMed] 